\title{
INCIDENCE OF POST-DURAL PUNCTURE HEADACHE USING DIFFERENT SIZES OF QUINCKE NEEDLES - A CLINICAL STUDY
}

\author{
Shivaramu Bidarakote Thammegowda, Prajwal Patel Holalu Shankarlinge Gowda ${ }^{2}$
}

${ }^{1}$ Assistant Professor, Department of Anaesthesia, AIMS, B. G. Nagar, Bellur, Nagamangala, Mandya. ${ }^{2}$ Assistant Professor, Department of Anaesthesia, AIMS, B. G. Nagar, Bellur, Nagamangala, Mandya.

\section{ABSTRACT}

\section{BACKGROUND}

Headache may be a troublesome feature after spinal anaesthesia. After the introduction of spinal anaesthesia, post-dural puncture headache has been an unfavourable complication. August Bier, father of spinal anaesthesia was the first to describe the classical features of dural puncture headache. The post-dural puncture headache has been a serious objection to the use of spinal analgesia especially in obstetric patients.

Objectives- 1. To find out the relationship of age, sex, weight and nature of the surgical procedure with post-dural puncture headache. 2. To find out the relationship between the incidence of post-dural puncture headache and the size of the spinal needle.

\section{MATERIALS AND METHODS}

The study population consisted of One thousand patients scheduled to undergo various selective and emergency surgeries under spinal anaesthesia. The study population was randomly allocated to receive spinal anaesthesia using 22, $23,24,25$ and 26 gauge spinal needles. In the post-operative period, patients were followed up for seven days. Specific enquiry was made regarding the presence of headache, its onset, severity, duration, postural variation and any association with visual, auditory disturbance and neck rigidity. After the study, qualitative analysis was made with respect to incidence of post-dural puncture headache and its affiliation with the needle sizes, nature of the surgery, sex, age and weight.

\section{RESULTS}

1. Younger age group are at higher risk of developing post-dural puncture headache. 2. Female patients have high incidence of post-dural puncture headache compared to males. 3. Obstetric and gynaecological cases carry high incidence of post-dural puncture headache. 4 . Thicker the size of the needle, more is incidence of post-dural puncture headache.

\section{CONCLUSION}

Incidence of post-dural puncture headache is lesser or nil by using finer size needles like 26 gauge and 27 gauge needle.

\section{KEYWORDS}

Post-dural puncture Headache, Sizes of Needle, Spinal Anaesthesia, Age, Weight.

HOW TO CITE THIS ARTICLE: Thammegowda SB, Gowda PPHS. Incidence of post-dural puncture headache using different sizes of Quincke needles - A clinical study. J. Evolution Med. Dent. Sci. 2017;6(7):510-514, DOI: 10.14260/Jemds/2017/108

\begin{abstract}
BACKGROUND
Headache following spinal anaesthesia is a perplexing problem to the anaesthesiologists. Post-dural puncture headache has been an unfortunate complication since the inception of spinal anaesthesia. August Bier, father of spinal anaesthesia was the first to describe the classical features of dural puncture headache. Following an attempted subarachnoid anaesthesia on August 24, 1898, he noted "All these symptoms (Pressure in the head and dizziness) disappeared as soon as I lie down horizontally but they return when I arouse". The post-dural puncture headache has been a serious objection to the use of spinal analgesia especially in obstetric patients. Many literatures have showed the theories of its cause as many.
\end{abstract}

Financial or Other, Competing Interest: None.

Submission 05-01-2017, Peer Review 17-01-2017,

Acceptance 19-01-2017, Published 23-01-2017.

Corresponding Author:

Dr. Shivaramu B. T,

\#1520, $7^{\text {th }}$ Cross, 2 ${ }^{\text {nd Main, }}$

Vivekananda Nagara, Mysore-23.

E-mail: prajwal.patel83@gmail.com

DOI: $10.14260 /$ jemds $/ 2017 / 108$

(c) $($ ) $\$$
Such a multiplicity of theories point up the lack of knowledge concerning the true genesis of these headaches. In the present study, an attempt was made to find out the incidence of post-dural puncture headache in patients posted for elective and emergency surgeries.

The Aim of the Study is to find out the incidence of postdural puncture headache with regards to age, sex, weight and nature of the surgical procedure.

To find out the relationship between the incidence of post-dural puncture headache and the size of the spinal needle.

\section{MATERIALS AND METHODS}

A clinical study comparing the incidence of post-dural puncture headache using different size spinal needles was carried out in the Department of Anaesthesiology, in Adichunchanagiri Institute of Medical Sciences, Bellur, Nagamangala Taluk during the period December 2015 to November 2016.

The study population consisted of One thousand patients scheduled to undergo various selective and emergency surgeries under spinal anaesthesia. The study population was randomly allocated to receive spinal anaesthesia using 22,23,24,25 and 26 gauge spinal needles.

A complete pre-anaesthetic checkup was done a day before surgery for the elective cases and for the emergency 
cases it was done on the day of the surgery and patients with the history of headache were excluded from the study. All the elective patients were premedicated with Tab. Diazepam 10 mg at night.

On the day of surgery, an intravenous line was established using 18 gauge IV cannula (Vasofix) and Dextrose saline injection was started. Under aseptic precaution with patient in a lateral decubitus position, lumbar puncture was attempted at L2-3/L3-4 space. After obtaining a free flow of cerebrospinal fluid, the local anaesthetic agent was introduced into the spinal space.

In the postoperative period, patients were followed up for seven days. Specific enquiry was made regarding the presence of headache, its onset, severity, duration, postural variation and any association with visual, auditory disturbance and neck rigidity. The headache was considered to be post-dural puncture headache, if it met the following characteristics.

1. Postural - relieved by lying supine and exacerbated by sitting or standing.

2. Severe or dull aching or throbbing in nature.

3. May be accompanied by nausea, vomiting, visual disturbance, tinnitus or deafness.

4. Whether the headache is occipital or frontal.

5. Neck stiffness and pain at the site of puncture.

Patients with headache after spinal anaesthesia were treated with analgesics, intravenous fluid and absolute bed rest until symptoms subsided. After the study, qualitative analyses were made with respect to incidence of post-dural puncture headache and its affiliation with the needle sizes, nature of the surgery, sex, age and weight.

\section{RESULTS}

\begin{tabular}{|c|c|c|c|c|}
\hline Sl. No & Age in Years & Male & Female & Total \\
\hline 1. & $17-25$ & 114 & 144 & 258 \\
2. & $26-35$ & 143 & 174 & 317 \\
3. & $36-45$ & 135 & 112 & 247 \\
4. & $46-55$ & 49 & 46 & 95 \\
5. & $56-65$ & 40 & 15 & 55 \\
6. & $>65$ & 24 & 4 & 28 \\
\hline \multicolumn{4}{|c|}{ Table I. Age Distribution of Cases } \\
\hline
\end{tabular}

\begin{tabular}{|c|c|c|}
\hline & M & F \\
\hline Maximum Age & 84 & 85 \\
\hline Minimum Age & 17 & 17 \\
\hline Mean Age & 41.31 & 33.64 \\
\hline
\end{tabular}

Mean age for 1000 cases 37.51.

Table 1 shows the age distribution observed in the present study. The maximum age observed in the present study is 85 years (Case No. 477) and the minimum age is 17 years (Case no. 84). The mean age is 37.51 years.

\begin{tabular}{|c|c|c|c|c|}
\hline Sl. No. & Weight in Kg. & Male & Female & Total \\
\hline 1. & $40-50$ & 20 & 87 & 107 \\
2. & $51-60$ & 332 & 372 & 704 \\
3. & $61-70$ & 149 & 34 & 183 \\
4. & $>70$ & 4 & 2 & 6 \\
\hline \multicolumn{4}{|c|}{ Table II. Weight Distribution of Cases } \\
\hline
\end{tabular}

\begin{tabular}{|c|c|c|}
\hline Maximum Weight & $90 \mathrm{~kg}$ & $70 \mathrm{~kg}$ \\
\hline Minimum Weight & $40 \mathrm{~kg}$ & $40 \mathrm{~kg}$ \\
\hline Average weight & $64.3 \mathrm{~kg}$ & $54.5 \mathrm{~kg}$ \\
\hline
\end{tabular}

Total mean weight for 1000 cases $=59.47 \mathrm{~kg}$.

Table II shows the weight distribution observed in the present study. The maximum weight observed in the present study is $90 \mathrm{~kg}$ (Case No. 265) and the minimum weight is 40 $\mathrm{kg}$ (Case No. 70). The mean weight is $59.47 \mathrm{~kg}$.

\begin{tabular}{|c|c|c|}
\hline Sl. No. & Nature of Surgical Procedures \\
\hline 1. & General Surgeries & 526 \\
2. & Orthopaedic & 149 \\
3. & Obstetrics (LSCS) & 99 \\
4. & Gynaec & 204 \\
5. & Urology & 22 \\
\hline \multicolumn{2}{|c|}{ Total } & $\mathbf{1 0 0 0}$ \\
\hline \multicolumn{2}{|c|}{ Table III. Nature of Surgical Procedures } \\
\hline
\end{tabular}

Table III shows the various surgical procedures carried out in the present study.

\begin{tabular}{|c|c|c|}
\hline $\begin{array}{c}\text { Total No. } \\
\text { of Patients }\end{array}$ & $\begin{array}{c}\text { No. of Patients who } \\
\text { Developed PDPH }\end{array}$ & Incidence \\
\hline 1000 & 28 & $2.8 \%$ \\
\hline \multicolumn{3}{|c|}{ Table IV. Showing the Incidence } \\
of Post-dural Puncture Headache \\
\hline
\end{tabular}

Table IV shows the incidence of post-dural puncture headache observed in the present study. Out of 1000 patients, 28 patients developed post-dural puncture headache giving an incidence of $2.8 \%$.

\begin{tabular}{|c|c|c|c|c|c|}
\hline Sl. No. & Age in Years & Male & Female & Total & $\%$ \\
\hline 1. & $17-25$ & 2 & 4 & 6 & 0.6 \\
2. & $26-35$ & 1 & 11 & 12 & 1.2 \\
3. & $36-45$ & 3 & 4 & 7 & 0.7 \\
4. & $46-55$ & - & 4 & 2 & 0.2 \\
5. & $56-65$ & 1 & - & 1 & 0.1 \\
6. & $>65$ & - & - & - & - \\
\hline \multicolumn{6}{|c|}{ Table V. Relationship between Age, Sex } \\
\hline \multicolumn{6}{|c|}{ and Weight of Patients out of 1000 Cases } \\
\hline
\end{tabular}

Table $\mathrm{V}$ shows the relationship between age, sex and weight of patients who developed post-dural puncture headache. 25 patients (89\%) who developed post-dural puncture headache were between the ages of 17-45 years and 15 of them were females posted mainly for lower segment Caesarean section (60\%).

2 patients aged between 46-55 years and 1 patient 56-65 years developed post-dural puncture headache. 
The incidence of post-dural puncture headache in females was more compared to males.

Out of 28 patients who developed post-dural puncture headache, females accounted for 21 cases and the remaining 7 patients were male.

\begin{tabular}{|c|c|c|c|c|}
\hline $\begin{array}{c}\text { Sl. } \\
\text { No. }\end{array}$ & $\begin{array}{c}\text { Size of } \\
\text { The } \\
\text { Needle }\end{array}$ & $\begin{array}{c}\text { Total } \\
\text { Number } \\
\text { of } \\
\text { Patients }\end{array}$ & $\begin{array}{l}\text { No. of Patients } \\
\text { who Developed } \\
\text { Headache }\end{array}$ & $\%$ \\
\hline $\begin{array}{l}1 . \\
2 . \\
3 . \\
4 . \\
5 .\end{array}$ & $\begin{array}{l}22 G \\
23 G \\
24 G \\
25 G \\
26 G\end{array}$ & $\begin{array}{c}354 \\
380 \\
190 \\
67 \\
9\end{array}$ & $\begin{array}{c}21 \\
7 \\
- \\
- \\
-\end{array}$ & $\begin{array}{c}5.9 \% \\
1.8 \% \\
- \\
- \\
-\end{array}$ \\
\hline & Total & 1000 & 28 & $2.8 \%$ \\
\hline
\end{tabular}

Table VI The table shows the relationship between size of the needle and occurrence of post-dural puncture headache.

The incidence of post-dural puncture headache after 22 gauge needle was $5.9 \%$.

380 patients were given spinal anaesthesia with 23 gauge needle, out of this 7 patients developed post-dural puncture headache giving an incidence of $1.8 \%$ with 23 gauge needle.

None of the patients who were given spinal anaesthesia with 24, 25 and 26 gauge spinal needles developed any postdural puncture headache.

\begin{tabular}{|c|c|}
\hline General Surgical and Orthopaedic Procedures & 11 \\
\hline LSCS & 7 \\
\hline Gynaec Cases & 9 \\
\hline Bilateral Abd, Tubectomy & 1 \\
\hline Total & 28 \\
\hline
\end{tabular}

Table VII shows the relationship between the nature of surgical procedures and post-dural puncture headache.

Out of the 28 patients who developed post-spinal headache, 11 patients underwent general, surgical and orthopaedic procedures. If caesarean section is alone taken, out of 99 patients who underwent lower segment caesarean section, 7 patients developed post-dural puncture headache giving an incidence of nearly $7 \%$.

\section{DISCUSSION}

In spite of the progress made in the field of intravenous anaesthesia, even today spinal anaesthesia enjoys a wide popularity in the developing nations. The reasons for it are spinal anaesthesia produces adequate anaesthesia with good muscle relaxation and the entire anaesthetic procedure may be attended to before the operation is begun (Sixten Haraldson). Spinal anaesthesia disturbs the physiological milieu into a minimum and the patient's consciousness and cooperativeness during the surgery.

\section{Relationship of Age to the Incidence of Post-dural puncture Headache.}

Sushan Brother et al (1996) noted that patients in the age group of 20-40 years are more likely to develop post-dural puncture headache. Incidence of post-spinal headache is significantly lower in older patients than in younger patients. The reasons offered for this is older people have an altered pain sensitivity of vascular pain receptors and the narrowed route of escape of CSF (Spielman 1982. Kankun 1981). Vandom et al noted that there is high incidence of Post-dural puncture headache in the age group 20-39 years (30\%).

\section{Relationship with Sex}

Sushan Brothers et al noted that women are more likely to be affected with post-dural puncture headache than men when the risk is adjusted to age. According to Schofield (1957), the sex bound difference in the incidence of post-dural puncture headache is due to emotional, hormonal factors. Vandom et al also noted that there is a higher incidence of post-dural puncture headache in female patients.

In the present study too, out of 28 patients who developed post-dural puncture headache, 21 patients were female and only seven patients were male. The higher incidence of post-dural puncture headache in females observed in the present study concurs with the studies of Sushan Brothers, Vandom et al, and Bonica et al.

\begin{tabular}{|c|c|}
\hline Name of the Author & Surgical Procedure \\
\hline Rasmussen (1989) & Hip replacement \\
\hline Campbell (1993) ${ }^{1}$ & Caesarean section \\
\hline Mayer et al (1992) & Caesarean section \\
\hline Ross et al (1993)² & Caesarean section \\
\hline $\begin{array}{l}\text { Toffoletto F. } \\
\text { et al (1993) }\end{array}$ & Knee Joint Arthroscopy \\
\hline Buettner J. et al (1993) ${ }^{9}$ & Surgeries on lower extremities \\
\hline Devcic A et al ${ }^{3}$ & Emergency/elective \\
\hline$(1993)$ & Caesarean sections \\
\hline Present Study & $\begin{array}{c}\text { General and orthopaedic surgeries } \\
\text { Obstetric and Gynec Procedures } \\
\text { Only caesarean section }\end{array}$ \\
\hline \multicolumn{2}{|c|}{ Relationship with Nature of Surgical Procedures } \\
\hline
\end{tabular}

\section{Relationship between Weight and Incidence of Post-dural} puncture Headache

Sushan Brothers et al noted that a lower body mass index is related to a greater risk of post-dural puncture headache. In morbidly obese obstetric patient, the post-dural puncture headache rate is significantly lower than in non-morbidly obese patients. In the present study, all the patients who developed post-dural puncture headache had their weight in the range of $51-70 \mathrm{~kg}$. None of the patients who were weighing more than $70 \mathrm{~kg}$ developed post-dural puncture headache, this concurs with findings of Sushan Brothers.

\section{Relationship of the Size of the Spinal Needle}

The following table shows the incidence of post-dural puncture headache by various authors, different size spinal needles ranging from 22 gauge to 26 gauge.

\begin{tabular}{|c|c|c|c|c|}
\hline Sl. No. & Gauge & Dripps (1924) & Greene (1926) & Phillips \\
\hline 1. & 16 & $26 \%$ & $30 \%$ & - \\
2. & 19 & $10 \%$ & $18 \%$ & - \\
3. & 20 & $14 \%$ & $14 \%$ & $14 \%$ \\
4. & 22 & $9 \%$ & $8 \%$ & - \\
5. & 24 & $6 \%$ & $2 \%$ & $3 \%$ \\
6. & 26 & - & $<1 \%$ & - \\
\hline
\end{tabular}


Dittmen et al in 1988 noted that there is universal consensus about the fact that the thicker the lumbar puncture needle higher could be the Incidence of post-dural puncture headache. ${ }^{4}$

Vandam et al (1956) noted that the incidence of postdural puncture headache with 16 gauge needle to be $18 \%$, with 19 gauge needle to be $10 \%$ and with 20 gauge needle to be $14 \%$. He also noted that when the spinal needle size is reduced to 22 gauge the incidence was lowered to $9 \%$ and with 24 gauge it was $6 \%$.

Table Showing the Relationship of the Size of the Spinal needle Table $A$.

\begin{tabular}{|c|c|c|c|}
\hline Authors & Sample & Size & $\begin{array}{c}\% \text { of } \\
\text { Headache }\end{array}$ \\
\hline 1. Sunderg (1992) & $22 Q$ & 25 & - \\
\hline 2. Lynch $(1992)^{5}$ & $22 \mathrm{~W}$ & 100 & $5 \%$ \\
\hline 3. G.Pittoni (1995) & $22 \mathrm{~S}$ & 117 & $0.8 \%$ \\
\hline 4. Jones et $\mathrm{al}^{6}$ (Myelogram) & $22 Q$ & 107 & $58.2 \%$ \\
\hline 5. Peterman et al (Myelogram) & $22 Q$ & 340 & $15.6 \%$ \\
\hline 6. Tourtellotte ${ }^{7}$ (Bevel tip) & $22 Q$ & 100 & $36 \%$ \\
\hline 7. Jones et al6 (Bevel tip) & $22 \mathrm{Q}$ & - & 37.5 \\
\hline 8. S.B. Peterson (1996) & $22 \mathrm{~W}$ & 340 & $16 \%$ \\
\hline 9. Dripps et al ${ }^{8}$ & $22 \mathrm{~W}$ & - & $27 \%$ \\
\hline 10. Present study & $22 \mathrm{Q}$ & 4952 & $9 \%$ \\
\hline & $22 Q$ & 354 & $5.9 \%$ \\
\hline \multicolumn{4}{|c|}{ Table A } \\
\hline Present Study & $23 \mathrm{G}$ & 380 & $1.8 \%$ \\
\hline \multicolumn{4}{|c|}{ Table B } \\
\hline
\end{tabular}

\begin{tabular}{|ll|l|c|c|c|c|}
\hline 1. & Trakkila (1992) & \\
2. & Cessonini (1990) & $24 \mathrm{G}$ & 83 & $2.4 \%$ & $1.1 \%$ & \\
3. & Mayer (1992) & $24 \mathrm{G}$ & 55 & - & - & \\
4. & Lim (1992) & $24 \mathrm{G}$ & 28 & $0.7 \%$ & - & \\
5. & Wiesel (J993) & $24 \mathrm{G}$ & 47 & $13.0 \%$ & & $3.5 \%$ \\
6. & Barnet A Green et al & $24 \mathrm{G}$ & & $2.5 \%$ & & $6.3 \%$ \\
& (1949) & & & & \\
7. & Present Study & $24 \mathrm{G}$ & 190 & $0.0 \%$ & & \\
\hline \multicolumn{7}{|c|}{ Table C } \\
\hline
\end{tabular}

\begin{tabular}{|ll|c|c|c|c|}
\hline 1. & Buettner (1993) & 25 G & 200 & $3 \%$ & $0 \%$ \\
2. & Lynch (1991) $^{5}$ & $25 \mathrm{~W}$ & 100 & $2 \%$ & $0 \%$ \\
3. & Campbell (1993) & $25 \mathrm{~W}$ & 150 & $0.7 \%$ & $0.7 \%$ \\
4. & Ramssen (1989) & $25 \mathrm{Q}$ & 95 & $12.6 \%$ & $\mathrm{NA}$ \\
5. & G.Pittoni (1995) & $25 \mathrm{~S}$ & 234 & $0 \%$ & $0 \%$ \\
6. & Wechler et al & $25 \mathrm{G}$ & & $0.6 \%$ & \\
7. & Ashwh et al (1995) & $25 \mathrm{G}$ & & $0.0 \%$ & \\
8. & Present Study & $25 \mathrm{G}$ & 67 & $0.0 \%$ & \\
\hline \multicolumn{5}{|c|}{ Table D } \\
\hline
\end{tabular}

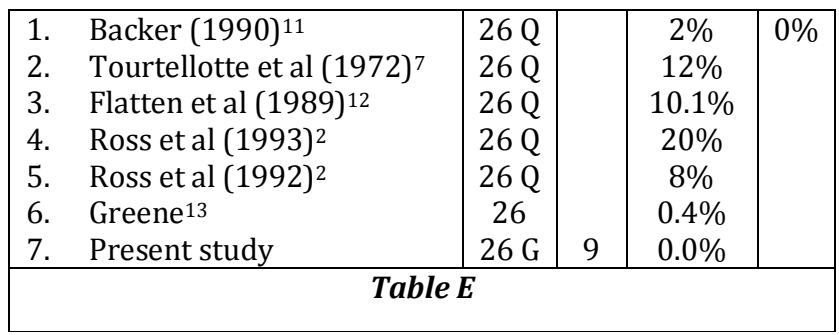

\begin{tabular}{|c|c|c|c|}
\hline $\begin{array}{c}\text { Needle } \\
\text { Gauge }\end{array}$ & $\begin{array}{c}\text { No. of Spinal } \\
\text { Anaesthetics }\end{array}$ & $\begin{array}{c}\text { No. of } \\
\text { PDPH }\end{array}$ & (\%) \\
\hline 16 & 839 & 151 & 18 \\
\hline 19 & 154 & 16 & 10 \\
\hline 20 & 2698 & 377 & 14 \\
\hline 22 & 4952 & 430 & 9 \\
\hline 24 & 634 & 37 & 6 \\
\hline
\end{tabular}

Because of the fact that smaller sized spinal needles have a lower incidence of post-dural puncture headache, the use of smaller size needles like 22, 23, 24, 25, 26 gauge, for spinal anaesthesia purposes has become a routine procedure and because of this, the incidence of post-spinal headache is also reduced very significantly.

\section{CONCLUSION}

1. Incidence of post-dural puncture headache is around $2.8 \%$ in patients undergoing various elective surgical procedures.

2. Patients aged between 20-40 years are at higher risk of developing post-spinal headache.

3. Female patients have a high incidence of post-dural puncture headache compared to males.

4. Obstetric and gynaecological cases carry high incidence of post-dural puncture headache.

5. Thicker the size of the needle, more is incidence of postdural puncture headache.

6. By using finer size needles like 26 gauge and 27 gauge needle, the incidence of post-dural puncture headache can be reduced to nil.

\section{REFERENCES}

[1] Campbell DC, Douglas MJ, Taylor G. Do the newer spinal needles reduce coring. Anesthesiology 1993;79:A478.

[2] Ross BK, Chadwick HS, Mancuso JJ, et al. Sprotte needle for obstetric anaesthesia: decreased incidence of postdural puncture headache. Reg anesth 1992;17(1):29-33.

[3] Devcic A, Sprung J, Patel S, et al. PDPH in obstetric anesthesia: comparison of 24-gauge Sprotte and 25-gauge Quincke needles and effect of subarachnoid administration of fentanyl. Reg Anesth 1993;18(4):2225.

[4] Dittmann M, Schafer HG, Ulrich J, et al. Anatomical reevaluation of lumbar dura mater with regard to postspinal headache. Effect of dural puncture. Anaesthesia 1988;43(8):635-7.

[5] Lynch J, Kasper SM, Strick K, et al. The use of Quincke and Whitacre 27-gauge needles in orthopaedic patients: incidence of failed spinal anaesthesia of post-dural puncture headache. Anaest Analg 1994;79(1):124-8.

[6] Jones RJ. The role of recumbency in the prevention and treatment of post-spinal headache. Anesth Analg 1974;53(5):788-96.

[7] Tourtellotte WW, Henderson WG, Tucker RP, et al. A randomized, double-blind clinical trial comparing the 22 versus 26 gauge needle in the production of the post-lumbar puncture syndrome in normal individuals. Headache 1972;12(2):73-8. 
[8] Dripps RD, Vandam LD. Long-term follow-up of patients who received 10,098 spinal anesthetics: failure to discover major neurological sequelae. J Am Med Assoc 1954;156(16):1486-91.

[9] Tarkkila PJ, Heine H, Tervo RR. Comparison of Sprotte and Quincke needle with respect to post-dural puncture headache and backache. Reg Anaesth 1992;17(5):283-7.

[10] Buettner J, Wresch KP, Klose R. Post-dural puncture headache: comparison of 25-gauge Whitacre and Quincke needles. Reg Anaesth 1993;18(3):166-9.
[11] Barker P. Headache after dural puncture. Anaesthesia 1989;44(8):696-7.

[12] Flatten H, Rodt SA, Vamnes J, et al. Post-dural puncture headache. A comparison between 26 and 29 gauge needles in young patients. Anaesthesia 1989;44(2):1479.

[13] Greene NM. Perspectives in spinal anaesthesia. Reg Anaesthetist 1982;7:55-62. 